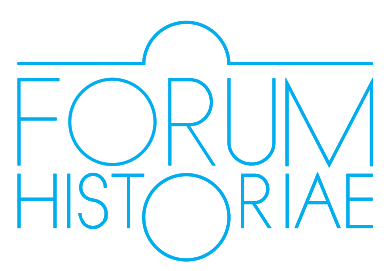

\title{
Vznik a činnost' Židovskej ústrednej úradovne
}

\author{
Katarína Mešková Hradská
}

\begin{abstract}
:
MEŠKOVÁ HRADSKÁ, Katarína: The Establishment and Activities of the Jewish Central Office.

The Jewish Central Office was established as a result of the political changes that took place after the establishment of the Autonomous Slovakia in October 1938. It was an attempt by some Zionists, Jewish Zionist Party leaders, to adapt to the new reality. The relatively short period of the existence of the Jewish headquarters was not only marked by an internal struggle between Zionists and members of the Orthodox Jewish religious community but also by loyalty to the government of Jozef Tiso.
\end{abstract}

Keywords: Jewish Central Office, Jews, Zionists, Orthodox, Loyalty, Autonomous Government, Jewish Newspaper

DOI: https://doi.org/10.31577/forhist.2019.13.1.8

$\check{\mathrm{Z}}$

idovská komunita na Slovensku a jej politická reprezentantka v podobe Židovskej strany ${ }^{1}$ prechádzali pred vznikom autonómneho Slovenska turbulentnými zmenami. Od roku 1919 celoštátne pôsobiaca Židovská strana, zložená väčšinou zo sionistov, si nárokovala na spojenie celej židovskej komunity. Hlavné body jej pomerne všeobecne ladeného programu sa týkali politického zjednotenia československých Židov s ciel'om dosiahnut' ich zastúpenie v Národnom zhromaždení, čo zodpovedalo ambíciám (pražskej) Národnej rady židovskej. Tá svoje požiadavky sformulovala do základných programových téz: uznanie židovskej národnosti vrátane možnosti slobodne sa prihlásit’ k židovskej národnosti, preferovat’ občiansku i verejnoprávnu rovnoprávnost' s ostatným obyvatel'stvom republiky, vytvorenie kultúrnej samosprávy vrátane židovskej výchovy a pestovania hebrejčiny, ale aj boj proti antisemitizmu, ktorý sa stal zásadným problémom narúšajúcim dovtedajšiu rovnováhu vztáahov medzi majoritou a minoritou. Zástupcovia Židovskej strany preto vyzývali predstavitel'ov republiky, aby nedovolili prerastanie antisemitizmu a aby včas zasiahli proti akýmkol'vek prejavom neznášanlivosti voči židovskej minorite a proti obmedzeniu občianskych práv Židov.

\footnotetext{
* Štúdia vznikla v rámci grantu VEGA č. 2/006/16: Politické, kultúrne a ekonomické elity židovskej komunity v rokoch 1918 - 1945. Vedúca riešitel'ského kolektívu PhDr. Katarína Mešková Hradská, PhD.

1 Vznikla v januári 1919 v rámci prvého celoštátneho stretnutia národných Židov, ktorý demonštroval vôlu presadit' práva občanov židovskej národnosti. Jej členská základňa bola zložená väčšinou zo sionistov. BližŠie pozri: MEŠKOVÁ HRADSKÁ, Katarína. Formovanie židovskej národnej myšlienky po vzniku 1. ČSR. In HANULA, Matej - KŠIŇAN, Michal (eds.) Slovensko a Európa medzi demokraciou a totalitou. Bratislava : VEDA, 2017, s. 107-114.
} 
Slovenskí Židia tvorili integrálnu súčast' československého židovstva. Po prvom zjazde národných Židov (Praha, 4. - 6. januára 1919) sa v marci 1919 v Pieštanoch konštituoval L'udový zväz Židov pre Slovensko, ktorý nadviazal na činnost' Národnej rady židovskej a aj v nasledujúcom období s ňou aktívne spolupracoval pri obhajobe politických, sociálnych a ekonomických záujmov slovenských Židov. Na Slovensku okrem toho časom pôsobilo aj viacero menších židovských strán, ktoré sa pred parlamentnými aj komunálnymi vol'bami síce usilovali upevnit' svoje pozície, ale v konečnom dôsledku nijako výrazne neovplyvnili výsledky volieb ani politické ambície svojich predákov. Dlhodobé rozdielne náhl'ady na židovskú politiku na Slovensku, ktorú v priebehu rokov vedenie Židovskej strany označilo za nezlučitel'nú so základnými sionistickými princípmi, sa v roku 1929 podpísalo pod štiepenie celoštátnej Židovskej strany. Výsledkom tohto procesu bolo odpútanie sa od pražskej centrály a vytvorenie samostatnej Židovskej strany na Slovensku. Strana v rôznych podobách, sprevádzaných vnútrostraníckymi rozpormi, jestvovala až do konca októbra 1938, ked' bola nútená zastavit' svoju činnost'. Treba poznamenat', že slovenská odnož Židovskej strany bola v podstate snahou, či viac-menej úspešným pokusom o etablovanie sa na politickej scéne. Jej vnútorná organizácia a $\mathrm{v}$ neposlednom rade aj početné personálne nezhody i názorové rozpory voličov však boli zdrojom napätia. Ani to nezabránilo paradoxnej situácii: na politickej scéne Československa pôsobili dve Židovské strany. Jedna so sídlom v Prahe a neskôr v Moravskej Ostrave (v záverečnej fáze ju viedol Emil Margulies) a druhá v Bratislave pod vedením Júliusa Reisza. Ten sa postupne stal hybnou silou slovenského židovstva, odmietol pražskú diktatúru a chcel na Slovensku vybudovat' organizačne silnú provládnu stranu, nezávislú od pražských politických exponentov, stranu s vlastným politickým programom a vzmáhajúcou sa členskou základňou. ${ }^{3}$ V marci 1939, ked' bol rozpustený pražský parlament, ukončila svoju činnost' aj Židovská strana s centrálou v Moravskej Ostrave.

\section{Vznik Židovskej ústrednej úradovne}

Zmeny, ktoré sa na Slovensku uskutočnili na jeseň 1938, signalizovali nielen zmenu politickej orientácie, ale aj nárast antisemitizmu a prehlbovanie protižidovských nálad v spoločnosti. Na túto hrozbu sa v Židovskej strane síce usilovali včas reagovat', avšak vela priestoru na svoje aktivity už nemali.

Po vyhlásení autonómneho Slovenska v októbri 1938 sa Židia na Slovensku ocitli na prahu novej reality. Vývoj nového Slovenska, ktorý síce označili za dynamický, zároveň ho chápali aj ako dejinný zvrat, ktorý ich oprávnil k vyjadreniu presvedčenia, že nové Slovensko pod vedením Hlinkovej slovenskej l'udovej strany (HSL'S)

2 MEŠKOVÁ HRADSKÁ, Katarína. Vznik židovských politických strán na Slovensku po vzniku 1. ČSR. V tlači. Okrem Židovskej strany bola rozpustená aj strana Poale Sion, ako aj všetky židovské záujmové spolky - pozn. aut.

3 Nie je cielom tejto štúdie podrobne sa zaoberat’ zložitou problematikou Židovskej strany a jej miestom v politickom systéme medzivojnového Československa, čo je predmetom d'alšieho výskumu autorky. Bližšie k téme pozri aj: BOREK, David.Zidovské strany v politickém systému Československa 1918 - 1938. In Moderní dějiny, 2003, roč. 11, s. 65-199; CRHOVÁ, Marie. Politické strany a politika židovské menšiny. In MALÍŘ, Jiří MAREK, Pavel (eds.) Politické strany: Vývoj politických stran a hnutí v českých zemích a Československu 1861 - 2004. 1. Období 1861 - 1938. Brno : Nakladatelství Doplněk, 2005, s. 965-985. 
židovskej komunite zabezpečí možnost' d’alšej existencie a rozmachu. Toto vyjadrenie Oskara Neumanna, sionistu a popredného predstavitel'a Židovskej strany, však možno chápat’ s určitými rezervami. Nádej na prosperitu totiž nepochybne sprevádzali aj obavy z dôsledkov neskrývanej protižidovskej politiky HSL'S, ktorá nadobúdala charakter štátnej politiky.

Postavenie slovenských Židov po októbri 1938 bolo ovplyvnené zmenou politickej klímy. Sionisti zo zaniknutej Židovskej strany avizovali vznik novej organizácie, ktorá by reagovala na spoločenské zmeny. Bratislavské Židovské noviny ${ }^{4}$ oznámili, že 4. novembra 1938 sionista Oskarom Neumann ${ }^{5}$ spolu s Eugenom Wintersteinom $^{6}$, Otom Löblom ${ }^{7}$ a rabínom Arminom Friederom ${ }^{8}$ založili Židovskú národnú radu pre Slovensko. Vo vyhlásení, ktoré vzápätí predložili židovskej verejnosti, vyjadrili presvedčenie, že mladé autonómne Slovensko bude potrebovat’ pokojné a harmonické spolužitie všetkých občanov vrátane Židov, ktorí „ako prvok pokoja, hospodárnosti a kultúrneho snaženia budú môct’ ponúknut’ dobré a cenné služby".9

Predstavitelia židovskej komunity v novej vláde videli možného garanta svojich občianskych aj náboženských slobôd. Na mieste je otázka, či mali inú vol'bu. Vzhl'adom na okolnosti im však nič iné ani zostávalo, len verbálne novú vládu podporovat' a prejavovat' sa ústretovo. Preto sa k novému režimu a k vládnej moci stavali od začiatku lojálne. Nádejali sa, že nová vláda bude mat’ záujem o súčinnost’ Židov pri riešení problémov, ktoré budú Slovensko sprevádzat'. Aby zmobilizovali svojich súvercov a usmernili ich, prípravný výbor Židovskej národnej rady pre Slovensko vydal Manifest, v ktorom stálo:

\begin{abstract}
„Uskutočnil sa dávny sen národa slovenského za autonómiu. Slovenské židovstvo privítalo tento akt spontánnymi prejavmi lojality. Uistili sme vládu slovenskú, že sme ochotní úprimne spolupracovat' na zvel'ad'ovaní dŕžavy slovenskej a že úprimne chceme pomáhat' pri spravodlivom rozložení všetkých problémov. Dávame svoje sily do služieb Slovenskej Krajiny a tohto štátu, lebo chceme ich zdarný vývoj a úspech. Zapojujeme sa do práce ako celok a každý jednotlivec a preto chceme sa vnútorne posilnit' a zjednotit’ pre tažké úlohy, ktoré nás čakajú.
\end{abstract}

Preto chceme ako Židia d’alej pestovat'svoj náboženský a národný život, aby sme predovšetkým židovskej mládeži v najužšom spojení s našimi všetkými ethnic-

4 Židovské noviny, orgán Židovskej strany a sionistov. Založené 20. mája 1938 v Bratislave. Vydavatel' Eugen Winterstein, zodpovedný redaktor Oto Löbl, tlač Kníhtlačiareň Ehrenthal, Ventúrska 7 Bratislava, náklad 3 000 kusov.

5 Oskar Jirmejahu Neumannn (1894 - 1981) - sionista, spoluzakladatel' a člen vedenia Židovskej ústrednej úradovne, neskôr Ústredne Židov, na jeseň 1944 deportovaný do Serede, odtial' do Terezína, po vojne pracoval ako vedúci združenia robotníkov pracujúcich v Izraeli (tzv. Histadrut).

6 Eugen Winterstein (1903 - 1970) - pôyodne zubný technik, vedúca osobnost' sionistického hnutia na Slovensku, spoluzakladatel' a člen vedenia Židovskej ústrednej úradovne, vydavatel' Židovských novín. V roku 1939 emigroval do Palestíny.

7 Oto Löbl (1903 - 1970) - právnik, spoluzakladatel’ a člen vedenia Židovskej ústrednej úradovne, po roku 1939 emigroval do Palestíny.

8 Armin Frieder (1911 - 1946) - rabín v Novom Meste nad Váhom, spoluzakladatel’ a člen vedenia Židovskej ústrednej úradovne, neskôr člen ilegálnej Pracovnej skupiny pri Ústredni Židov, na jeseň 1944 deportovaný do Serede, v apríli 1945 utiekol z transportu.

9 Židovské noviny, roč. 1, č. 20, 4. novembra 1938, s. 1. 
kými hodnotami dodali duševný a mravný obsah, zvlášt' nutný pre t’ažký život dneška. To znamená zachovat' a vybudovat’ všetky naše kultúrne, náboženské, hospodárske a sociálne inštitúcie, dobudovat' tieto inštitúcie zriadením organizácií, poverených všetkými životnými a národnými problémami židovstva. Úlohy, ktoré treba vyriešit' ako nasledovné: musíme čím skôr započat's d'alekosiahlym prevrstvovaním, čo do povolania zriad'ovat' poradne pre vol'bu zamestnania, sprostredkovatel'ne práce a taktiež akademická mládež nutne potrebuje ustanovizne podporné a hospodárske. Šport a telovýchova, ktoré boli až dosial' $v$ našich židovských telocvičných a športových spolkoch úspešne pestované, musíme pestovat' i nad'alej, lenže intenzívnejšie než dosial'.

Organizácia celého židovského života, židovská hospodárska a úverná pomoc, ochrana našich oprávnených životných záujmov si vyžaduje koncentrovanie všetkých židovských síl. Konečne musí byt' riešená ciel'avedome ústredne organizácia vystahovalectva.

K riešeniu týchto a tiež iných sa zatial' nie presne vymedzených úloh spojili sa dnešným dňom všetky židovské organizácie na Slovensku v Židovskú národnú radu, ktorá sa bude snažit' upravit'v dohode s vládou krajiny Slovenskej životne dôležité problémy židovstva na Slovensku, zapadajúce do jej kompetencie.

Židia!

\section{Učme sa od okolitého sveta!}

Jednota, disciplína a cit povinnosti to sú vel'ké tvorivé sily, ktoré je nám treba k rozumnej úprave nášho života.

Voláme Vás všetkých k zodpovednej a dôveryhodnej spolupráci."10

Z uvedeného je zrejmé, že prípravný výbor Židovskej národnej rady pre Slovensko načrtol úlohy, ktoré bolo treba naliehavo riešit’. Okrem organizovania celého židovského života vrátane prevrstvovania na rozličné povolania išlo o zriad'ovanie poradní pre vol'bu zamestnania, vytvorenie sprostredkovatel'ní práce, ale aj o pomoc pre akademickú mládež, školstvo, telovýchovu a šport. Ako pozitívne sa javí, že ešte koncom novembra 1938 Židovská národná rada zastrešovala všetky vtedajšie židovské organizácie, ktoré v tom čase ešte mohli fungovat'. Charakterizovala ich rôznorodost' a aj to, že Židia často nenašli spoločný prienik a postupovali nekoordinovane. Jednotní neboli ani v politickej rovine. Proti sebe stáli prívrženci sionistického smeru, združení v Židovskej strane, a predstavitelia ortodoxnej náboženskej orientácie. ${ }^{11}$ Ich spor o politické postavenie mal svoje korene ešte v časoch, ked' sa v Prahe začala formovat' celoštátna organizácia československého židovstva. Nepretržité spory sionistov a ortodoxných Židov nedávali nádej na

10 Tamže.

11 Sionizmus propagoval ideu židovského národa na vlastnej pôde, teda v Palestíne. Prinášal novú interpretáciu židovstva, vnímal ho ako moderné národné spoločenstvo, resp. ako moderný židovský nacionalizmus. Idey sionizmu prenikali na Slovensko pomalšie ako v Čechách. Slovenské židovstvo bolo z vel'kej časti ortodoxné, konzervatívne a myšlienku sionizmu v podstate odmietalo. Prívrženci ortodoxného smeru vo svojej filozofii uprednostňovali rabínov, v rukách ktorých sa mala sústredit’ všetka moc. 
skoré zjednotenie a v podstate trvali až do obdobia, ked' sa najviac očakával ich jednotný postup a spoločná obrana proti nastupujúcemu nebezpečenstvu. Proces ich zdanlivého zjednotenia sa niesol v znamení nekonečných diskusií o zmysle židovskej práce a židovského života vôbec, ale najmä obáv z budúcnosti. Ked’ autonómna vláda v novembri 1938 prikročila k zastaveniu činnosti viacerých politických strán ${ }^{12}$ vrátane Židovskej strany s odôvodnením, že nepôsobia v záujme zachovania verejného poriadku a bezpečnosti na Slovensku, predstavitelia židovskej komunity pochopili, že vláda nielenže cielavedome likviduje politický pluralizmus, ale odmieta brat' do úvahy aj existenciu samotnej Židovskej národnej rady. Na situáciu bolo treba reagovat': Židovská národná rada sa pretransformovala do Židovskej ústrednej úradovne pre krajinu Slovensko (v d’alšom texte aj ako Žúú) s cielom zaoberat' sa aktuálnymi problémami Židov na Slovensku. Príčina zmeny názvu je nad’alej otázkou diskusie, no na základe Neumannových pamätí sa možno domnievat', že „vládnym nacionalistom nevyhovovalo, že si Židia vybrali historický názov Rada "13 a preto radšej názov svojej organizácie zmenili. Jej vznik avizovali Židovské noviny už 24. novembra 1938. Z publikovaného oznamu v novinách je zrejmé, s akým ciel'om táto centrálna reprezentantka slovenského židovstva mieni pôsobit': „Po rozsiahlom zjednotení všetkých židovských organizácií, ktoré boli doteraz zlúčené v Židovskej Národnej rade, utvorila sa teraz ako ústredná reprezentácia celého židovstva Židovská ústredná úradovňa pre Krajinu Slovensko. Toto celkové zastúpenie slovenského židovstva, ktoré je založené na dôvere všetkých Židov, je kompetentnými inštanciami Slovenska uznané. Úlohou tejto ústrednej úradovne je zmierne vyriešenie všetkých otázok a problémov s pomocou patričných úradov týkajúcich sa celého židovstva." "14 Taktiež leták, ktorý sa objavil na rôznych miestach Slovenska a ohlasoval vznik ústrednej úradovne, vyzýval všetkých Židov, aby si plnili svoje občianske povinnosti pri budovaní hospodárstva Slovenskej krajiny, pričom je nanajvýš potrebná jednota, disciplína, náboženské i národné sebavedomie i vel'ké tvorivé sily. ${ }^{15}$ Týmito slovami apelovali aj na ortodoxnú Ústrednú kanceláriu autonómnych ortodoxných židovských náboženských obcí, aby sa k novej ustanovizni pripojila. Ortodoxní túto ponuku odmietli, a dokonca presvedčili aj Zväz židovských náboženských obcí na Slovensku (známy ako Ješurun), aby sa $\mathrm{k}$ iniciatíve Židovskej ústrednej úradovne nepripojil. Neumann tento stav prirovnal k žabomyšej vojne vnútri židovskej komunity, k vojne nervov, ktorá nikam nevedie, no ktorá by sa dala prekonat’ spoločným úsilím a dobrou vôlou všetkých strán vrátane ortodoxie. ${ }^{16}$ Ústredná reprezentácia židovstva na Slovensku aj na-

12 Jozef Tiso už 30. októbra 1938 na oslavách dvadsiateho výročia Martinskej deklarácie na margo politických strán vyhlásil: „Politické strany musia íst’ do čerta! Dost’ bolo straníckosti, politických legitimácií. My teraz potrebujeme iba jednu stranu, jednu legitimáciu, a to legitimáciu slovenského národa." FABRICIUS, Miroslav HRADSKÁ, Katarína (eds.) Jozef Tiso. Prejavy a články (1938 - 1944). Bratislava : Historický ústav SAV, 2007, dokument č. 13, s. 25. Pozri tiež: Slovenský národný archív, fond Ustredný hospodársky úrad, kartón 21, č. $11038 / 40$.

13 NEUMANN, Oskar Jirmejahu. Im Schatten des Todes. Ein Tatsachenbericht vom Schicksalskampf des slowakischen Judentums. Tel Aviv : Ed. Olamenu, 1956, s. 19.

14 Ústredná reprezentácia celého židovstva na Slovensku. In Židovské noviny, roč. 1, č. 22, 24. novembra 1938, s. 1.

15 Pozri: NIŽŇANSKÝ, Eduard. Holokaust na Slovensku. Obdobie autonómie 6. 10.1938 - 14. 3. 1939. Dokumenty. Bratislava : Nadácia Milana Šimečku, 2001, s. 40.

16 NEUMANN 1956, s. 31. 
priek tomuto prehlasovala, že jej činnost' musí byt’ založená na dôvere všetkých Židov. V praxi to znamenalo, že predstavitelia úradovne hodlali za každú cenu zjednotit’ všetky židovské politické frakcie a spoločenské i záujmové organizácie, čo sa však aj vzhladom na budúcnost' ukázalo ako komplikovaný proces.

\section{Zásahy proti židovskej minorite}

Predstavitelia Židovskej ústrednej úradovne nabádali na lojálny prístup k politike autonómnej vlády v nádeji na možnú vzájomnú spoluprácu. 0 svojom kladnom postoji k vláde Jozefa Tisa neustále ubezpečovali a prihovárali sa za mierovú spoluprácu. Ked' sa naskytla možnost' osobne s ním hovorit', hoci to bolo zriedkavo, znova prízvukovali, že celá židovská komunita dáva vláde k dispozícii svoje schopnosti. Ked’ židovská deputácia koncom októbra 1938 navštívila J. Tisa, odovzdali mu memorandum, v ktorom už vyjadrili svoje obavy z budúcnosti. Tiso memorandum prijal s ubezpečením, že Židia na Slovensku nemusia mat' obavy z antisemitizmu. Po prvej Viedenskej arbitráži, na základe ktorej Slovensko prišlo o svoje južné územie a odstúpilo ho Mad’arsku, Tiso pristúpil k prvému protižidovskému zásahu, ktorý dovtedy nemal v stredoeurópskom priestore obdobu. Historik Eduard Nižňanský na túto tému publikoval viacero vedeckých štúdií i kapitol v publikáciách, v ktorých sa odvoláva na dostatok relevantných dokumentov. ${ }^{17}$ Vo svojich prácach uvádza, že bezprostrednou reakciou slovenskej autonómnej vlády na prvú Viedenskú arbitráž, čo bola prvá nespochybnitel'ná zahraničnopolitická porážka Tisovej vlády, bolo označenie Židov za vinníkov tohto stavu a ich následné deportovanie na územie, ktoré po prvej Viedenskej arbitráži začalo Mad'arsko od 5. novembra 1938 obsadzovat'. Tiso tam nechal deportovat' približne 7500 zväčša nemajetných Židov z celého Slovenska. Mad’arská strana ich však odmietla prijat' a zhromaždených Židov začali odvážat' spät' na slovenskú hranicu. Nepohodlní Židia sa tak ocitli na slovensko-mad’arskej hranici. Na „území nikoho“ postupne vznikli dva tábory: v Miloslavove ned’aleko Bratislavy a vo Vel'kom Kýre pri Nitre. Z hl'adiska témy pokladám za zásadný postoj predstavitelov Židovskej ústrednej úradovne, ako aj druhej židovskej organizácie, Ústrednej kancelárie autonómnych ortodoxných židovských náboženských obcí, ktoré na novembrové deportácie Židov reagovali vcelku rozumne. Nezávisle od seba navštívili predsedu vlády Jozefa Tisa, aby intervenovali za prepustenie vyhnaných Židov. ${ }^{18}$ Ortodoxní tak urobili 29. novembra 1938 a zástupcovia Židovskej ústrednej úradovne 4. decembra 1938. Zachoval sa list ortodoxnej židovskej náboženskej obce adresovaný ministerskému predsedovi J. Tisovi so žiadost'ou o možnost' návratu deportovaných Židov. Okrem iného sa v ňom píše, že l’udia sú už dva týždne premiestňovaní z miesta na miesto, momentálne ich odsunuli naspät’ k hraniciam Slovenska. Nachádzajú sa vo vel'mi zlej situácii, mnohí z vel’kej zimy t’ažko ochoreli. V Miloslavove je umiestnených 302 Židov, z toho 120 mužov, 77 žien a zvyšok sú deti

17 NIŽŇANSKÝ, Eduard. Nacizmus, holokaust, slovenský štát. Bratislava : Kalligram, 2010, s. 45 a iné. Nielen v tejto publikácii autor uvádza, že 4. novembra 1938 J. Tiso po stretnutí s policajným riaditelom a prezidiálnym šéfom ministerstva vnútra skorigoval svoje rozhodnutie týkajúce sa deportácií nemajetných Židov a deportovaní mali byt' len Židia bezdomovci „a Židia, ktorí nemajú domovské právo v obci, kde sa zdržujú, nech sú urýchlene vypovedaní do ich domovských obcí." NIŽŇANSKY 2001, s. 48.

18 NEUMANN 1956, s. 18. 
rôzneho veku, dokonca aj dojčatá. Zaujímavé sú aj dalšie údaje: z celkového počtu je 17 občanov zo Slovenska, 30 pochádza z Podkarpatskej Rusi (v origináli citátu ako: „aus der Karpatoukraine“), 22 l'udí z Pol'ska, 28 z Nemecka, 167 l'udí je bez štátnej príslušnosti. Podobná situácia je vo Vel'kom Kýre - z 344 deportovaných je 132 mužov, 73 žien a 139 detí. Ortodoxní J. Tisovi navrhli niekol'ko možností. $\mathrm{V}$ prípade, že by sa vrátili do svojich domovov, postarajú sa o ubytovanie, stravu aj lekárske vyšetrenie. ${ }^{19}$

Medzi obomi židovskými deputáciami u J. Tisa, teda 2. decembra 1938, uverejnili Židovské noviny slovami O. Neumanna postoj Židovskej ústrednej úradovne. Neumann v ňom prejavil znepokojenie i súcit s tými, čo boli internovaní (deportovaní) v spomenutých táboroch: „Obyčajne sa nám predstavuje pojem Zem nikoho ako nevinný kus polá, lesa alebo lúky, ako priekopa pri hradskej, kus vol'nej prírody, pravda l'udskej zvôle uzavretej kolom dokola neviditel'nými hranicami. A tento obyčajne nepatrný kus krajiny dostáva svoj krutý význam až v okamihu, ked' tragika udalostí zoženie sem násilne l'udí, ktorí náhlou skutočnostou, že sa na tejto pôde nachádzajú, sú bilagovaní ako l'udia bez domova a stávajú sa tými l'ud'mi bez práva a bez ochrany. Byt' bez domova a v zemi nikoho uzavretí len mračnami nad sebou a bodákmi, možno i ostnatým drôtom vôkol, je zaiste najhroznejším osudom, najkrutejším trestom, ktorý dnes môže stihnút' človeka [...] Videli ste už niekedy osud tých neštastných l'udí $v$ tábore, v zemi nikoho, bez toho, aby ste neboli dojatí v híbke svojej duše? Kde sú nútení žit' l'udia preto, lebo je ich jedinou vinou že sú Židmi? [...] V mene l'udskosti musíme pozdvihnút' hlas za tých to neštastných bratov a apelovat'na srdcia všetkých, ktorí ešte nestratili posledný cit pre l'udské strasti a l'udské utrpenia!'20

Po mnohých intervenciách sa židovským organizáciám podarilo dosiahnut' kompromis. Na základe rozhodnutia Krajinského úradu z 8. decembra 1938 bolo povolené Židom, ktorí sa nachádzali v spomenutých dvoch táboroch, vrátit’ sa do miest, odkial' boli deportovaní. Tiso, ako píše aj Nižňanský, už v novembri 1938 sledoval svoju antisemitskú líniu, ktorá mala korene v autochtónnom katolíckom antisemitizme. ${ }^{21}$ Reprezentanti Židovskej ústrednej úradovne, ale aj iných židovských organizácií mohli však už v tomto období sledovat' vývoj Tisovej antisemitskej politiky, s ktorou boli v podstate po prvýkrát konfrontovaní. Podcenili však vážnost' situácie, ktorá ich mala varovat' pred budúcimi atakmi zo strany Tisovej vlády.

V snahe byt' nápomocní pri riešení problémov si zástupcovia židovstva dostatočne neuvedomili, že Tisova autonómna vláda a jej štátostrana nepokladali Židov za politických partnerov, s ktorými by rokovali o dôležitých otázkach, a nejavili teda ani záujem s nimi spolupracovat' s výnimkou vystahovania Židov do Palestíny. Jozef Tiso to potvrdil aj 8. februára $1939 \mathrm{v}$ rozhovore so spravodajcom Židovskej telegrafnej agentúry, ktorý poskytol už po deportáciách nepohodlných Židov

19 Pozri: HUTZELMANN, Barbara - HAUSLEITNER, Mariana - HAZAN, Souzana. Die Verfolgung und Ermordung der europäischen Juden durch das nationalsozialistische Deutschland 1933 - 1945. Slowakei, Rumänien und Bulgarien. 13. Oldenbourg : Valter de Gruyter, 2018, dokument č. 7, s. 129 a n.

20 V mene l'udskosti! In Židovské noviny, roč. 1, č. 23, 2. decembra 1938, s. 1. Pozri tiež: HUTZELMANN HAUSLEITNER - HAZAN 2018, dokument č. 5, s. 125.

21 NIŽŇANSKÝ, Eduard. Židovská komunita na Slovensku medzi československou parlamentnou demokraciou a slovenským štátom v stredoeurópskom kontexte. Prešov : Universum, 1999; NIŽNANSKÝ 2010 a iné. 
na Mad’armi obsadené územie. V odpovedi na otázky Jozefa Fränkela uviedol, že: „Otázka židovská sa bude riešit' spravodlive, sociálne a l’udsky [...] slovenská vláda venuje pozornost' vyst’ahovalectvu Židov do Palestíny. Je to jasné aj zo schválenia transferu a vyst'ahovaleckého plánu $d r$. S. E. Soskina. ${ }^{22}$ Aké je pozadie tohto vyjadrenia? Tiso sa ešte začiatkom novembra 1938 stretol s generálnym riaditelom Palestínskeho kolonizačného úradu Seligom E. Soskinom, ktorý mu predložil plán emigrácie európskych Židov do Palestíny. ${ }^{23}$ Plán mal umožnit židovským záujemcom vyst'ahovat' sa zo Slovenska a založit' si novú existenciu na novom území bez toho, aby nastal odlev kapitálových hodnôt zo Slovenska. 0 spomínaných návrhoch rokovala aj Ministerská rada, ktorá poverila Ministerstvo hospodárstva tento problém rozpracovat' do detailov. Prvé rokovanie Poradného zboru pri Ministerstve hospodárstva sa zaoberalo „riešením židovskej otázky“ z hladiska slovenského podnikania, ako aj zabezpečením poriadku a pokoja vo verejnom podnikaní a účastou súkromného kapitálu na hospodárskej prestavbe Slovenska. Porada vyzvala na „premyslené etapové a evolučné riešenie týchto naliehavých problémov, ktoré zaistia želatel'ný rozmach slovenského národného hospodárstva “. ${ }^{24}$ Historici, zaoberajúci sa touto problematikou, sa zhodujú v názore, že Soskinov vystahovalecký plán sa nerealizoval.

\section{„Doba je vážna!“}

Jedným z dôkazov lojality Židovskej ústrednej úradovne a jej zástupcov k novému režimu boli vol'by do snemu Slovenskej krajiny. Prikročenie k urnám pokladali Židia za vel'kú zodpovednost' a za prejav občianskej povinnosti. Vo vyjadreniach Židovskej ústrednej úradovne k tejto dejinnej udalosti sa uvádza, že Židia nikdy nestáli bokom a ani v posledných radoch, ked' išlo o plnenie občianskych povinností. Preto v záujme budúcnosti krajiny aj židovskej komunity bolo nanajvýš potrebné zúčastnit' sa volieb a spečatit' tak túžbu prispiet' k zdarnému vývoju Slovenska. Židovské noviny preto uverejnili výzvu, ktorou apelovali na svedomie každého, komu záležalo na prosperite krajiny.

„Židia! Vážna je doba, v ktorej prikročíte k urnám. Na každom z Vás leží vel'ká a t’ažká zodpovednost'v chvíli, ked' vykonávajúc najhlavnejšie občianske právo a najsvätejšiu občiansku povinnost', dáte výraz svojmu presvedčeniu.

Treba si uvedomit', že len v pozitívnej práci a v pozitívnom postoji $k$ záujmom Slovenska môže záležat’ náš príspevok k zdarnému vývoju našej vlasti.

Volí sa prvý Slovenský Snem. Počítajú sa nielen hlasy, ale tiež počet osôb, ktoré vykonali svoju občiansku povinnost'. Výsledok tohto počítania bude merítkom, či obyvatel'stvo Slovenska pochopilo význam historickej chvíle a či je nadostač vyspelé, aby vládu svojich vecí si upravilo podl'a vlastného, dobre uváženého záujmu.

22 FABRICIUS - HRADSKÁ 2007, dokument č. 46, s. 64.

23 Židia do Palestíny! In Slovák, roč. 20, č. 256, 10. novembra 1938, s. 4.

24 Prvé rokovanie Poradného zboru pri Ministerstve hospodárstva. In Slovák, roč. 20, č. 259, 13. novembra 1938, s. 2. 
My Židia sme nikdy nestáli v posledných radoch, ked' išlo o konanie občianskych povinností. I teraz dokážeme, že vec slovenského národa, s ktorým dlhé stáročia spolunažívame, je naším najsvätejším a najhlavnejším zákonom.

Preto ukážme a dokážme, že i v týchto pohnutých časoch sme správne pochopili zmysel dejín.

Dostavíme sa všetci $k$ vol'bám a pri tomto slávnostnom akte odovzdáme svoj hlas za slovenský národ, za zdarný vývoj našej vlasti, za Slovenský Snem, za štátnost' Slovenska jako prejav nášho želania a našej viery, že všetky problémy, ktoré Slovenský Snem bude riešit', vyrieši spravodlivo a k dobru nášho štátu. ${ }^{25}$

V súlade s touto proklamáciou Židovská ústredná úradovňa vyzývala, aby sa Židia volieb masívne zúčastnili a na otázku „Chcete nové slobodné Slovensko?“ odpovedali kladne. Židia sa pred vol'bami vo svojich vyjadreniach nepretržite odvolávali na podmienku pokojného spolunažívania majority so židovskou minoritou, teda na rešpektovanie práva slovenského národa, voči čomu sa žiadny predstavitel' židovskej komunity neohradil, ale za predpokladu, že sa budú rešpektovat' aj najzákladnejšie a prirodzené l'udské práva Židov.

Parlamentné vol'by, tak ako sa 18. decembra 1938 uskutočnili, znamenali koniec vel'mi krátkeho obdobia parlamentnej demokracie na Slovensku. Vol'by charakterizovala jednotná kandidátka, vybičovaná protižidovská kampaň, oddelené volebné miestnosti, osobitné volebné urny pre Židov, asistencia gardistov, ktorí sledovali, kto ako volí. ${ }^{26}$

Slovenskí Židia aj napriek tomu, že na odporúčanie židovskej úradovne svorne hlasovali kladne, nemali v slovenskom sneme žiadne zastúpenie. Na otázku prečo tomu tak je, J. Tiso v rozhovore so spravodajcom Židovskej agentúry uviedol, že Židia (uviedol počet 87-tisíc) mali príležitost' podat' si vlastnú židovskú kandidátku, avšak neurobili tak. Na margo židovskej kandidátky dokonca uviedol, že delegácia slovenských Židov, ktorá na jednej strane zdôrazňovala svoju lojalitu k slovenskej vláde, na stretnutí s ním nepožadovala svoje zastúpenie v slovenskom sneme. ${ }^{27}$ Dôvody, prečo nepostavilo slovenské židovstvo svojho kandidáta, dostatočne nevysvetlili ani samotní najvyšší predstavitelia židovskej komunity, hoci mali dostatok príležitostí analyzovat' priebeh volieb a ich výsledky. Zmienku o tom nepriniesli ani Židovské noviny, ktoré aj napriek svojmu vplyvu na formovanie vedomia židovskej populácie upriamili svoju pozornost’ skôr na povolebné obdobie, teda na nastávajúce budovanie krajiny, aj ked' bez židovského zástupcu $\mathrm{v}$ slovenskom sneme.

25 Židovské noviny, roč. 1, č. 25, 16. decembra 1938, s. 1.

26 Bližšie pozri: NIŽŇANSKÝ, Eduard. Vol'by do snemu Slovenskej krajiny roku 1938. Dostupné na internete: http://www.dejiny.sk/Whois/Nizn/Artickles\%2017.htm.

27 FABRICIUS - HRADSKÁ 2007, dokument č. 46, s. 64. Denník Slovák v tejto súvislosti uviedol, že svoje zastúpenie v slovenskom sneme nemá 87-tisíc Židov. Tento číselný údaj prebrali aj d’alšie slovenské periodiká, ktoré sa týmto problémom zaoberali a odcitovali vyjadrenie J. Tisa. Historik I. Kamenec, citujúc uvedený rozhovor J. Tisa s Jozefom Fränkelom, uvádza počet 89-tisíc židovských občanov, čo zodpovedá počtu Židov žijúcich na Slovensku. KAMENEC, Ivan. Po stopách tragédie. Bratislava : Archa, 1991, s. 37. 
V súvislosti s vol'bami sa spomínajú osobitné volebné urny pre židovských voličov. Po vol’bách ich J. Tiso v denníku Slovák odôvodnil nasledovne: „Vynikajúci židovskí činitelia pred vol'bami žiadali pre židovských voličov osobitné urny. Kde to bolo možné, splnila sa ich žiadost' a oni sa osvedčili za nové a št'astné Slovensko. Nové Slovensko pristúpi iste $k$ vybaveniu židovskej otázky, ale k vybaveniu zákonitému, $v$ čom znovu len vyhovie žiadosti Židov, ktorí sa nevzpierajú definitívnemu vyriešeniu svojho problému. "28 Tiso sa vzápätí dotkol aj židovského kapitálu. Jeho spravodlivé rozdelenie a využitie v službách celku (štátu, K. H.) pokladal za nevyhnutné a naliehavé, pričom očakával, že židovská strana túto situáciu, resp. požiadavku pochopí.

Hlavný rabín Hugo Stránsky aj napriek tomu, že Židia nemali v sneme svojho legitímneho zástupcu a svoj hlas odovzdali jedinej politickej strane, čím sa stali súčastou takmer 1,3 milióna platných hlasov, prirovnal existenciu snemu k výraznej konsolidácii pomerov a za významnú udalost’ v celoeurópskom rozsahu. Základ tejto - podl'a rabína - novej štátnej tvorby mal byt' nielen národný, ale aj náboženský. „A práve preto sa aj nás Židov ako náboženskej menšiny dotýka nová tvárnost' slovenskej krajiny. "29 Väčšina židovských rodín už bola v tom čase zakorenená do slovenského prostredia a aj židovská mládež sa preorientovala a zrástla so slovenskou kultúrou. Znova a až privel'mi optimisticky vyzneli rabínove slová o tom, že aj židovský l'ud sa vyslovil za príchod novej vlády. „Prebojovala sa rozvaha a rozumnost'. V tomto duchu sa dnes schádza nový slovenský snem [...] Upierame svoje zraky na tento snem v nádeji, že budú uskutočňované prejavy krest'anskej lásky a spravodlivosti, tol'kokrát aj na nás adresované. ${ }^{30} \mathrm{~V}$ atmosfére lojality a s neskrývaným optimizmom sa vyjadroval aj 0. Neumann, čo možno pripísat' nielen jeho predstavám o vzájomnom rešpektovaní, ale aj dôvere k slovenskému snemu. V nastupujúcom období sa však mohol viackrát presvedčit' o tom, že vzájomné rešpektovanie je $\mathrm{v}$ podstate len jednostranné želanie, ktoré nestálo na reálnych základoch.

Vrcholní predstavitelia Židovskej ústrednej úradovne, ktorí verejne vyjadrovali podporu vláde i snemu, s napätím (a či s nádejou?) očakávali príhovor ministerského predsedu J. Tisa na druhej schôdzi snemu 21. februára 1939. Tiso sa v ňom viackrát odvolával na historickú úlohu slovenského národa pri budovaní nového štátu, na národný svojráz slovenského národa, po stáročiach si budujúci svoj štát, ktorý nemá byt šovinistický, neznášanlivý a práva iných národov nerešpektujúci štát. To, čo podla Tisa znepokojovalo slovenských Židov, nesúviselo s protižidovskými opatreniami slovenskej vlády, ale obávali sa toho, že rovnaké opatrenia uplatňované v Nemecku po nástupe Adolfa Hitlera k moci sa budú zavádzat’aj na Slovensku. Tiso tieto obavy nijako nerozplynul. Skôr naopak. Židovská otázka bola pre neho otázkou medzinárodnou, pretože sa ňou zaoberali všetky národy,

28 Slovenský snem bude mat' 63 poslancov. In Slovák, roč. 20, č. 289, 23. decembra 1938, s. 1.

29 Židovské noviny, roč. 2, č. 3, 20. januára 1939, s. 1.

30 Tamže, s. 2. 
mala sa riešit' aj na Slovensku. $\mathrm{V}$ prejave na zasadaní snemu preto uviedol, že: „Je dôkazom zrelosti nášho národa, že slovenský národ napriek všetkým povzbudeniam vyčkal zákonné vyriešenie židovskej otázky a ubezpečujem slovenský národ, že pri riešení židovskej otázky nebudeme mat' pred očami nič iného, ako záujem slovenského národa. ${ }^{\text {‘1 }}$

\section{Snemovanie v Žiline}

Zásadným medzníkom v d’alšej existencii židovskej úradovne bol zjazd Židovskej ústrednej úradovne pre Krajinu Slovenskú. Konal sa 22. januára 1939 v Žiline, teda mesiac pred druhým zasadaním slovenského snemu. Pozvanie na zjazd dostali zástupcovia viacerých židovských organizácií vrátane zväzov náboženských obcí, krajinské organizácie Agudat Jisrael ${ }^{32}$ (ortodoxná organizácia, ktorá však podporovala sionizmus), Achduth, spolok vysokoškolákov, Brith Trumpeldor, čo bola organizácia židovských skautov, sionistická organizácia Hebrejský jazykový a školský spolok pre Slovensko, záchranná organizácia HICEM, Palestínsky úrad, d’alej Hechaluz, športový klub Makabi, Zväz slovenských Židov, ale aj židovská ženská organizácia WIZO, ktorá mala na Slovensku významné postavenie, a d’alšie organizácie. Svojou prítomnost'ou potvrdili záujem zjednotit’ slovenské židovstvo, a to aj napriek tomu, že vzájomná nezlučitel'nost' ideí sa už dlhodobo podpisovala pod polarizáciu slovenského židovstva. Židovská verejnost' očakávala, že zjazd dá návod na riešenie problémov, pochybností aj otázok, s ktorými v komunite denne zápasili. Vedúci predstavitelia úradovne však priznali, že do Žiliny neprišli s programom riešit' židovskú otázku na Slovensku v tom zmysle, že si zvolia panický odchod domov bez toho, že by sa dopracovali k nejakému riešeniu. Vel'ký význam pripisovali nielen tvorbe a rozvíjaniu morálnych a duševných hodnôt, ale aj zaradeniu Židov do hospodárskeho života. Netajili sa tým, že sa spoliehajú na pochopenie slovenskej vlády, ktorá by im mala umožnit' pôsobit' aj v tejto oblasti. ${ }^{33}$ Pripomenuli, že židovský podnikatel' je schopný a ochotný urobit' všetko, čo mu jeho schopnosti dovolujú, ale zároveň sa treba zbavit’ stereotypného názoru o finančnej zdatnosti Židov, čo nie je nič iné ako vplyv židovského podnikatel'ského ducha. Vyslovili vôlu slovenského židovstva dat' všetky duchovné aj hmotné prostriedky do budovania novej slovenskej spoločnosti.

Zjazd, ktorý sa niesol v duchu lojality k novej vláde (delegáti vyslovili jednotnú vôlu slovenského židovstva dat' všetky svoje hmotné aj duchovné prostriedky do služieb budovania Slovenska), zaznamenal nezanedbatel'ný pozitívny výsledok: Delegáti zjazdu totiž uznali Židovskú ústrednú úradovňu za jedinú reprezentant-

31 FABRICIUS - HRADSKÁ 2007, dokument č. 48, s. 69 a n. To, že židovská otázka sa chápala ako medzinárodný problém, deklarovali aj iné periodiká: „O židovskej otázke sa u nás v ostatné dni hovorilo vel'a a ako zo správ vysvitá, táto otázka je aktuálna vo všetkých stredoeurópskych štátoch." Slovenský hlas, roč. 1 , č. 240,20 . októbra 1938 , s. 1 . Dostupné na internete: http://digitalna.kniznica.info/zoom/24852/ view?page=1\&p=separate\&view=0,0,3424,5107.

32 Izraelská historička Gila Fatranová uvádza, že z pozvaných organizácií sa zjazdu nezúčastnil jedine Agudat Jisrael. FATRANOVÁ, Gila. Boj o prežitie. Bratislava : SNM - Múzeum židovskej kultúry, 2007, s. 23.

33 Slovenská vláda mala už v tomto období so židovskou komunitou iné úmysly. Pozri: Štát musí vyradit’ Židov z hospodárskeho a verejného života. In Slovák, roč. 26, č. 34, 10. februára 1939, s. 1. 
ku Židov na Slovensku, čo tiež nebolo jednoduchým procesom. Na zjazde totiž zazneli aj hlasy, aby sa prítomní zástupcovia ortodoxných Židov obrátili na všetky kruhy ortodoxie s výzvou, aby sa zasadili za úplnú jednotu židovstva na Slovensku a aby túto tendenciu deklarovali vstupom do (sionistickej) Židovskej ústrednej úradovne. Splnenie tejto vízie by bolo zaiste prekvapením, pretože ešte pred žilinským zjazdom vedenie ortodoxných Židov nebolo ochotné pripustit' inú alternatívu než odmietat' kooperáciu s ostatnými organizáciami. Boli presvedčení o správnosti svojho rozhodnutia s nikým nespolupracovat', a naopak, všemožne organizovat' zánik ŽÚÚ. Sionisti však mali problém aj s vedením zväzu Ješurun, teda Zväzom židovských náboženských obcí, ktorých nepresvedčili o správnosti svojej politiky. Ako problematický sa ukázal predseda zväzu Ješurun Arpád Kondor, ktorý dostatočne nepochopil podstatu problematického vztahu ortodoxného vedenia k židovskej úradovni a spojil sa s ortodoxným Izidorom Pappenheimom. Rivalita, názorové rozkoly medzi ŽúÚ a ortodoxnými spôsobili dlhotrvajúce napätie, ktoré malo vyriešit' niekol'ko vzájomných stretnutí s cielom dosiahnut' kompromis. Pochopit' problém neochoty ortodoxných proti pripojeniu k ŽÚÚ si však vyžaduje samostatný výskum histórie Agudat Jisrael, a to od zjazdu ortodoxných židovských náboženských obcí, ktorý sa konal začiatkom decembra 1919 v Bratislave.

Spomínaný žilinský zjazd sa napriek prvotným obavám, ktoré vyvolala výzva predsedu krajinskej ortodoxnej organizácie I. Pappenheima, aby jednotlivé obce bojkotovali žilinský zjazd, sa napokon konal v duchu zjednotenia, čo sl'ubovalo koniec politikárčenia. Vyjadrenie popredného funkcionára ŽÚÚ E. Wintersteina o tom, že len jednotné židovstvo na Slovensku bude spolupracovat' na výstavbe Slovenska, vyvrcholilo v konštatovaní, že dohoda s ortodoxiou sa stala v zásade skutočnost'ou, ${ }^{34}$ vd’aka čomu získala Židovská ústredná úradovňa mandát na to, aby slovenských Židov zastupovala v rokovaniach s úradmi. Obsiahla rezolúcia žilinskej konferencie o. i. vyjadrila presvedčenie, že „úprava otázok týkajúcich sa budúceho slovenského národa so židovským občianstvom na Slovensku bude sa diat' na základe spravodlivosti a krestáanskej lásky k blížnemu“. ${ }^{35}$ Realita, ktorá nastala dva mesiace po zjazde, bola jednoznačnou odpoved'ou na to, akým smerom sa uberala spravodlivost' a krest'anská láska $\mathrm{k}$ blížnemu. Aj preto sa všetky aktivity ŽÚÚ sústredili na problémy, ktoré boli dôsledkom vnútropolitického i medzinárodného vývoja vrátane vládnej protižidovskej politiky. Prioritou sa stalo nielen poskytovanie pomoci židovským utečencom, ktorí prišli na Slovensko zo susedných štátov, ale aj nezamestnanost' v súkromnom sektore, $\mathrm{v}$ priemysle a slobodných povolaniach. Odporúčania nájst' si novú prácu a zapojit' sa tak do budovania priemyslu i pol'nohospodárstva, sa viac-menej javili ako volanie o pomoc. Preto sa začali pripravovat' rekvalifikačné kurzy, budovali sa rozličné preškolovacie centrá, čo Židovská ústredná úradovňa koordinovala s každou židovskou náboženskou obcou.

34 Zo zjazdu. In Židovské noviny, roč. 2, č. 4, 27. januára 1939, s. 1. Toto vyjadrenie bolo však viac želaním ako realitou - pozn. aut.

35 Rezolúcie žilinskej konferencie. In Židovské noviny, roč. 2, č. 4, 27. januára 1939, s. 4. 


\section{Preškol’ovanie v záujme vyst’ahovania}

Na čoraz nepriaznivejšiu situáciu slovenských Židov po vyhlásení autonómie predstavitelia Židovskej ústrednej úradovne komunity zareagovali organizovaním dobrovol'nej emigrácie do Palestíny a iných štátov, ktoré boli ochotné poskytnút' slovenským Židom azyl i pracovné uplatnenie. Predovšetkým nemajetní Židia tak nepriamo reagovali aj na slová J. Tisa, ktorý deklaroval záujem slovenskej vlády o ich vyst'ahovanie zo Slovenska. Možnost' vyst'ahovat' sa využilo niekol'ko tisíc Židov, ktorí boli odkázaní na pomoc zahraničných záchranných organizácií. Šancu mali predovšetkým fyzicky aj psychicky zdatní jedinci a absolventi preškolovacích kurzov na povolania potrebné na prácu v cudzine. Zachránili sa tak pred deportovaním do koncentračných táborov v okupovanom Pol'sku a celkom iste aj pred smrtou v plynových komorách.

Vyst’ahovanie židovských občanov organizačne patrilo do kompetencie Židovskej ústrednej úradovne pre Slovensko, ktorá už od svojho vzniku skúmala možnosti vyst'ahovania. Židovská úradovňa prijala podmienky platné pre všetky štáty, ktoré organizovali vyst'ahovanie Židov zo svojho územia. Platilo, že vystahovalectvo do ktoréhokolvek štátu pre nemajetných Židov vo veku do 35 rokov bolo podmienené patričnou duševnou a fyzickou prípravou, ktorá bola nevyhnutná na okamžité zaradenie do vystahovaleckého poradovníka. Príprave na vystáahovanie zo Slovenska slúžili prípravné tábory, rozličné prevrstvovacie (preškolovacie) kurzy, do ktorých sa prijímali iba osoby, ktoré svojou telesnou zdatnost'ou zabezpečovali úspešný priebeh celej akcie. Nevyhnutnou podmienkou prijatia do tohto procesu bol starostlivý výber jedincov nielen z vekového hladiska, ale aj z hladiska výberu povolania. Kým v zámorských krajinách sa uplatňovali viac remeselníci, v Palestíne išlo predovšetkým o pol'nohospodárske práce, ktoré zabezpečovali nielen prechodné uplatnenie, ale aj trvalú prácu, vd’aka čomu sa vyst'ahovalci mohli vyhnút' počiatočným problémom spojeným s chudobou. Ked'že od zastupitel'ských úradov poskytujúcich možnost' vystáahovat' sa prichádzali nové a nové smernice, v Ústrednej židovskej úradovni sa sústredili na organizovanie preškolovania na základné remeslá, s ktorými sa dalo uplatnit' všade na svete a ktoré by mali byt' polahčujúcou okolnostou pri získaní povolenia na vystahohovanie. Aby sa však mohli vytvorit' podmienky na fyzické prevrstvovanie (na zámočníkov, murárov, obuvníkov, krajčírov atd'.), bolo treba prispôsobit' sa aj psychicky, pretože situácia slovenských Židov sa po októbri 1938 podstatne zhoršila, a len duševne odolní jedinci boli schopní tomuto čelit'. Celková nepriatel'ská atmosféra a antisemitské prejavy spôsobili, že otázka vystahohovania zo Slovenska bola pre mnohých primárnou otázkou, ktorou by vyriešili svoju budúcu existenciu. Preto sa organizované preškol'ovacie kurzy stretali s vel'kým záujmom najmä v radoch židovskej mládeže. Zabezpečovali pružné prispôsobovanie sa novým podmienkam na život v budúcej domovine, teda v Erec Israel. ${ }^{36}$

36 Bližšie pozri: MEŠKOVÁ HRADSKÁ, Katarína. Vyhnanci, alebo emigranti? Vyst’ahovalecké akcie zo Slovenska po vzniku autonómneho Slovenska. In MICHÁLEK, Slavomír a kol. Obraz a odraz osobnosti modernej doby. Bratislava : VEDA, 2019, s. 253-267. 
Židovská ústredná úradovňa mala k dispozícii Židovské noviny, no členov komunity informovala o svojich aktivitách aj prostredníctvom obežníkov. Posledný z nich vyšiel v júli 1940 a obsahoval informácie o protižidovských nariadeniach a zákonoch vrátane arizácie židovského majetku, o pripravovaných programoch vystahovania zo Slovenska i o možnostiach rekvalifikačných kurzov s praktickými radami, ktoré reagovali na zhoršené podmienky, v ktorých sa slovenskí Židia ocitli. Otázkou je, či v tom čase aktuálne i nastupujúce protižidovské opatrenia boli dôvodom na to, že židovská ortodoxia prehodnotila svoje rozhodnutia a prejavila ochotu so sionistami napokon aj spolupracovat', hoci s vel'kými výhradami a s pocitom rozčarovania na oboch stranách. Večný boj ortodoxných so sionistami, počas ktorého ani jedna strana nebola ochotná prekročit' svoj vlastný tieň, sa prejavil aj v posledných dňoch existencie Židovskej ústrednej úradovne na začiatku septembra 1940, ked' sa už vedelo o tom, že vznikne, resp. že bude štátom nanútená d'alšia židovská organizácia, ktorej členmi museli byt' povinne všetci židovskí občania.

Z hladiska dnešného poznania by bolo možné (vel'mi zjednodušene) uviest', že existencia Židovskej ústrednej úradovne nemala nejaký osobitný význam. Aktivity, ktoré organizovala napríklad v oblasti kultúry a vzdelávania, mohli totiž vykazovat', a do istej miery tak aj robili, ostatné židovské organizácie, pokým neboli úradne rozpustené. Treba však brat' do úvahy, že v čase svojho krátkeho pôsobenia žÚÚ nebola ešte konfrontovaná s neskoršou realitou v podobe tvrdých protižidovských zákonov a nariadení. Preto ju skôr označujem za predvoj budúcej židovskej organizácie, ktorá už musela riešit' úplne iné (rozumej existenčné) problémy židovskej komunity. Za významné pokladám to, že Židovská ústredná úradovňa zastrešovala všetky v tom čase pôsobiace židovské organizácie. Na druhej strane snaha za každú cenu zjednotit’ sionistov s ortodoxnými sa ukázala ako náročný dlhodobý proces a nie vždy úspešný. Zakladatel'mi Židovskej ústrednej úradovne boli väčšinou členovia niekdajšej Židovskej strany, sionisti, ktorí sa usilovali nájst' istú alternatívu k spôsobu komunikácie ortodoxných Židov s predstavitel'mi vládnucej politickej strany. Mienili tak robit' prostredníctvom legitímneho politického boja, ktorý bol založený predovšetkým na zásade rešpektovania l’udských práv. Ich politická práca však nezriedka vyvolávala prehnaný optimizmus, s čím sa do istej miery možno iba čiastočne stotožnit', resp. chápat' to ako primeranú reakciu na situáciu. Reprezentanti Židovskej ústrednej úradovne boli totiž zväčša príslušníkmi mladšej generácie. Spomedzi nich bol najstarší O. Neumann, ktorý mal v tom čase 45 rokov, kým ostatní boli zhruba o desat' rokov mladší. Boli to intelektuáli, ktorí si vážili hodnoty demokratického zriadenia prvej ČSR, boli plní energie a odhodlania podporit' pre židovskú komunitu pozitívne politické zmeny. Na druhej strane treba uviest', že v čase svojho pôsobenia sa nachádzali v inej situácii, nemali ešte natol'ko zviazané ruky protižidovskými nariadeniami ako ich nasledovníci v Ústredni Židov. Tú naoktrojovala vláda tri týždne po rozpustení 
Židovskej ústrednej úradovne. ${ }^{37}$ Prostredníctvom Ústredného hospodárskeho úradu sa nová židovská centrála stala nástrojom vládnych orgánov, ktoré prevzali kontrolu nielen nad ňou, ale v podstate nad celou židovskou komunitou.

37 Židovská ústredná úradovňa bola rozpustená 3. septembra 1940, Ústredňa Židov bola založená 26. septembra 1940. Bližšie o tom pozri: HRADSKÁ, Katarína. Holokaust na Slovensku 8. Ústredňa Židov (1940 - 1944). Dokumenty. Bratislava : Klemo, 2008.

\section{Cituj:}

MEŠKOVÁ HRADSKÁ, Katarína. Vznik a činnost' Židovskej ústrednej úradovne. In Forum Historiae, 2019, roč. 13, č. 1, s. 116-130. ISSN 1337-6861. DOI: https://doi.org/10.31577/forhist.2019.13.1.8

PhDr. Katarína Mešková Hradská, PhD.

Oddelenie novších dejín

Historický ústav SAV

P. O. Box 198

Klemensova 19

81499 Bratislava

Slovenská republika

histhrad@savba.sk 